\title{
МОНГОЛООР СУДАРЧИЛЖ ХЭВЛЭСЭН ДӨРВӨЛЖИН ҮСГИЙН СУБАШИДЫН ШИНЭ ХУУДАС
}

\author{
Р.Отгонбаатар \\ Хэл зохиольн хүрээлэн \\ Цахим шуудан: onggud@gmail.com
}

Энэ зууны эхээр, өнгөрөгч зууны эцсээр алдарт Дунхуанаас ахин дахин малтаж олсон ховор хуучин номын дотроос зарим хэсгийг нь эрдэмтэд хэвлэн нийтэлж уншин тайлж эхлэв. Үүнээ эрдэмтэн Гарьд ${ }^{1}$, Төмөртогоо 2 , Отгон ${ }^{3}$ нарыг эн тэргүүн дурдах нь зүйтэй юм. Учир нь Дунхуаны Мөөгөө агуй сүм орчмоос олсон эрт цагийн ном судрын хэсэг бусаг тасархай дотроос дөрвөлжин үсгээр монгол хэлээр сударчлан хэвлэсэн “Сайн үгт эрдэнийн сан” нэрт сургаалын гурав, дөрвөн жижиг тасархай илэрчээ. Үүнээс гурвыг нь эвлүүлээд нэгэн хуудсын дунд хэсгийн 11 мөр бүхий 30 гаруй үгтэй томоохон дурсгалыг сэргээн босгожээ. Мөн ганц үг нь гаргацтай нэгэн жижиг тасархай тамтархай гарсан нь өнчрөн сондгойрч үлдэн хоцорсон байна. Эл жижиг тасархай мөн нэгэн шинэ хуудас болох тухай энд өгүүлнэ. УГ тасархай нь В 163:77 гэсэн олдворын дугаартай, 4,3х6,4 см хэмжээтэй ажээ 4 . Энэхүү нэг бүтэн үгтэй жижиг тасархайг өмнө нийтэлж судалсан эрдэмтэд чухам ямар номын тасархай болохыг хараахан тодорхойлоогүй билээ. Гэсэн хэдий ч энэ бол дээрх Субашидын тасархай мөн төдийгүй нэгэн шинэ хуудас төлөөлөх тухай товч тодруулъя. Өмнөх эрдэмтэд ч нэг доор малтлагаас хамт гарсан тул Субашидын тасархай гэж таамаглаж байсан буй за. Гэвч хажуугийн хагас үсгүүдийн үлдэгдлийг хараахан бүрэн гүйцэд зөв уншаагүй учраас ямар номын тасархай болохыг тодлон таниагүй бололтой байна.

Эл дурсгалын эхийг үзэж эхлэн уншсан Өвөр монголын судлагч эрдэмтэн Гарьд “ir-ge-ni” гэдэг үгийн өмнөх мөрийн үгийн хойд хэсгийг ажиглаад “dü円-gü”s хэмээн сэргээн тэнхрүүлэхээр оролджээ. Гэвч тун эргэлзээтэй харагдсан учир нь үсгийн болон үгийн галигт үеийн байдлыг нэг л болмооргүй тохиромжгүй сэргээсэн байв. Монгол бичгийн их энхэлгэ буюу эншилгэ хэмээх дэвсгэр үсэг нь төвд үсгийн бяцхан “a” буюу огтор “a” хэмээх үсэгтэй дүйдэг бөгөөд дөрвөлжин бичигт ч гийгүүлэгчээр эхэлсэн үеийн дээр дан ганцаар өөрөөр хэлбэл эгшиггүйгээр тохиолддоггүй билээ. Энэ үсэг нь ямагт эгшгийн доор хамт байдаг дэвсгэр үсэг болдог учир сэргээн уншиж хэвлэсэн мэт “gü" үеийн дээр тохиолдох учиргүй гэж хувиасаа хардаж сэрдээд өөрөөр унших оролдлого хийж эхлэв. Мөн Монголын эрдэмтэн Төмөртогоо нар эл үгийг хэвээр үлдээн галиглаж даган баясаад хойд мөрийн “о”” эгшгийг нэмж зөв уншсан юм. Харин Ланжоу хотын Баруун хойдын үндэстний их сургуулийн багш судлаач Отгон бээр Гарьдын уншилтыг дурдан хэвээр “düng-ü(n)” гэж үлдээсэн билээ. Эдгээрээс уг тасархайг ямар номын аль хэсэг болохыг тодруулах боломжгүй байлаа.

Учир иймд уг тасархайг гүйцэд уншиж таньсан тухайгаa энэ бяцхан өгүүлэлд дэлгэрэнгүй баахан нуршиж өгүүлэх юм.

Дараалсан хоёр хуудас дарагдаад долоон зуун жил дулаан хуурай элстэй газрын хөрсөнд байхдаа арын хуудаснаас алганы хонхор хаах төдий ч хүрэхгүй буюу өнөөгийн манай нийслэл хотын нийтийн тээврийн унааны зорчих тасалбарын хэмжээ төдий цаас үлджээ. УГ цаасны бодит хэмжээг $6,4 \times 4,3$ см хэмээн жинхэнэ эхийг үзсэн судлаач тэмдэглэсэн нь ердөө л 
томхон эрхий дарам хэмжээний аж.

Үүнээ дундах нэг мөрийн нэг үг маш тодорхой. Түүний өмнөх мөрийн нэг үгийн хойд хэсэг хагас хугас цаашилбал хойд мөрийн хоёр үгийн урд хэсгийн цөөн зураас зурлага төдий нь хальт мөлт танигдахаар үлдсэн буй. Энэхүү гурван мөрийн дунд байгаа гагцхан шууд уншигдаж байгаа үг нь “...'ir-ge-ni /иргэнийг/... ” гэдэг үг билээ.

Бид сэргээн бичиж үзээд ухаалаг зөвөөр хэдий ойролцоо, нягт нямбай, эх бичигт дөхүү хувилбарыг тооцоолон гаргаж чадвал хэвлэлийн хэмжээ дамжааг ч бараг төлөв багцаалан гаргаад тоймыг мэдэж болмоор мэт. Үүний тодорхой баримт нь энэХүҮ ганц үгтэй эртний хэвлэлийн гэрч баримт бэлхнээ илтгэн харуулж чадах байна. Мэдээж энд өмнөх хуудас нь үлэмж тус болсныг хэлэх хэрэгтэй.

Ер энэ тасархай ямар ч эргэлзээгүй өмнөх эрдэмтэн судлаачдын таньж хэвлэсэн сударчилсан Субашидын дараагийн хуудас даруй гарцаагүй мөн байна. Бидэнд маш тодорхой мэдэгдэж байгаа зүйл бол 313 , 314, 315, 316 дугаар бадаг шүлэг бүхий нэгэн нүүрийн гол хэсэг байна. Энэ хуудасны дээд доод зах буюу барын хайрцаг хүрээнээс хөндлөн шугам давхар харагдавч нөгөө баруун зүүн талын хоёр захын босоо хүрээний давхар шугам нь үгүй болой. Хэдий тийм боловч 313 дугаар бадаг шүлгийн эцсийн мөр 314, 315 дугаар бадаг шүлгийн ихэнх хэсэг бүтэн 316 дугаар бадаг шүлгийн эхний мөр буй. Үүгээр сударчилсан номын үндсэн хэмжээг төсөөлөхөд нэгэн нүүрт 4-5 бадаг шүлэг багтаж, нүүр тал бүрийг ойролцоогоор дөрвөөс таван бадаг шүлгээр бичиж хэвлэсэн багцаатай байна. Учир иймд дараагийн нүүрт (317) 318, 319, 320, 321 дүгээр бадаг шүлэг байх ёстой. Мөн түүний дараагийн нүүрт ойролцоогоор (321) 322, 323, 324, 325 дугаар бадаг шүлэг тохиолдоно. Иймээс миний бүрэн уншин таньж байрлалыг тогтоосон гагц бүтэн үгтэй тасархай гарцаагүй том тасархайн буюу одоо байгаа нүүрийн арын хуудсанд бүр тодруулбал нэг нүүр алгасаад дараагийн нүүрт тохиож буй билээ. Харин дээд доод буюу өвөр ард байх нь өмнөх мэдэгдсэн шүлгүүдийн ар, өвөр талын алинд байхаас шууд шалтгаална. Мөн уг тасархай дээр монгол үсгээр ямар нэгэн зүйл бичсэн мэт харагдах тул бас монгол бичгээр хавсарган үзүүлэв.

Эл үгийн зэрэгцээ хоёр мөрийн хойдох мөрд буй өмнөх хагасын зураас зурлагаас “иргэнийг” гэдэг үгийн хойд талын мөрийн “о”" үсгийн доор "уо-su /ëc/" гэдэг үгийн “уа"-ийн гурван хувийн нэг, “sa” үсгийн хоёр хувийн нэг хүрэхгүй шахам нь илэрхий харагдаж буй тул түүгээр гул барин мөрдөн мөшгөж олсон гэдгийг зориуд тэмдэглэе. Сайтар ажваас “у”, (o), “s”, (u) зэрэг үсгийн урд өнцөг мэт тул мэдээж шууд yosu /ëc/ буюу уо-sun /ëсон/, yo-su-'ar? /ëcoop/ гэж хайсан билээ.

Зөвхөн 324 дүгээр бадаг шүлгийн эхний мөрийн “иргэнийг” гэдэг үг түүний өмнөх 323 дугаар бадаг шүлгийн эцсийн мөрийн “дүүрэн” хэмээх үг бас 324 дүгээр бадаг шүлгийн хоёрдугаар мөрийн “төр ёсоор” гэдэг үгс мөн. Бас Субашидын эртний орчуулга буюу Сономгараагийн орчуулгын дотор “иргэн” хэмээх үг 79, 219, 324, 360 дугаар бадаг шүлэгт тус бүр нэг удаа буюу нийт дөрвөн удаа тохиолдоно ${ }^{6}$. Түүнчлэн мөн үед монгол хэлээр дөрвөлжин үсгээр адилавтар хэмжээ хэлбэртэй хэвлэсэн “Мэдэгдэхүүнийг бэлгэтэеэ гийгүүлэгч шастир"-т “иргэнийг” хэмээх үг зургаан удаа нэг доор шахам гардаг. Үүнийг ч юмыг яаж мэдэх гээд сайтар нягтлан шалгахад тохирохгүй байсныг дашрамд дурдъя. Гэвч урд хойд мөрийн гурван үгийн хэсгийг уншсанаар уг үлтэрхий, тамтархай буюу ганц “иргэнийг” гэдэг үг нь чухам гагцхүү Субашидын 324 дүгээр шүлэгт л тохиолдохыг харж болно.

Энэхүу “иргэн” шиг эрт эдүгээгийн элдэв ном зохиолд элбэг олон гардаг ганц үгээр, ийм тийм номын энд тэнд гарах тохиолдол хэмээн тайлбарлахад бэрхтэй нь хэнд ч тодорхой. Харин эргэн тойрон хажуу хавирганд нь байх хоёр, гурав буюу 
дөрөв, таван үгийг таньж уншсан нөхцөлд ямар номын аль хавьд тохирч буйг танихад хялбар болой.

Ер нь уг сэдэвт холбогдох учир Сажагийн сайн номлол хэмээн алдаршсан Субашидын удаа дараагийн дөрвөлжин үсгийн монгол хэвлэлийн тухай товч тодруулан өгүүлбэл өмнө судлаачид нийтээр мэдэх болсон дэвтэрчилсэн хэвлэл нь бадаг шүлэг бүрийн эхний мөр шадын эхлэх үг бүрийг монгол бичгийн заншил ёсоор мөр тэтгэн дээш нэг үе илүү гаргаж бичээд барласан онцлог тодорхой харагдаж байна. Мөн нэгэн нүүр талыг арван мөртэй хэвлэжээ. Мөн шад мөр бүрийн төгсгөлд дан онги буюу нэг л онгин цэг тавьжээ. Харин бадаг шүлэг бүрийн төгсгөлд ямар нэгэн цэг тэмдэг тавилгүй хоосон төгсгөж орхиод шинэ шүлэг бадгаа мөр тэтгэн бичиж барласан нь ажиглагдана. Нэгэн мөрд дунджаар 5-6 үгс байна. Хааяа зарим мөрд богино үгс олон орвол 7-8 үгтэй буй. ИйнхүҮ Монголын дөрвөлжин үсгээр монгол хэлээр бичсэн Субашидын дэвтэрчилсэн хэвлэл нь ойролцоогоор гурван бадаг шүлэг нэгэн нүүрт буюу нэг талд багтсан дундажтай учир 160 орчим нүүр талтай 80 орчим хамар хуудас бүхий одоогийн бичгийн цааснаас үл ялиг томхон хэмжээний ном болгон хэвлэсэн нь тодорхой мэдэгдэж байна.

Нөгөө хэвлэл буюу сүүлд олдсон сударчилсан хэвлэлийн онцлог нь бадаг шүлэг бүрийг шинэ мөрөөс эхлэн шад мөр бүрийн эцэст давхар онги тавьж, бадаг шүлэг бүрийн төгсгөлд чандмань онги буюу гуравлан овоолсон онгин цэгээр дуусгасан байна. Энэ хэвлэлийн нэгэн мөрд дунджаар 3-4 үг буй. Хааяа богино үгс нэгэн доор орсон тохиолдвол нэг мөрд 5 үг оржээ. Шүлэг бадаг бүрийг шинэ мөрөөс мөр тэтгэлгүй бичиж, нэгэн нүүрт 20 орчим мөрөөр буюу тал тутамд дунджаар дөрвөн бадаг шүлэгтэй учир 110 гаруй тал нүүртэй буюу 60 орчим хуудастай их хөлгөн судар шиг том хэмжээтэй хэвлэл болно.

Ер Сажа нутгийн хоёр их эрдэмтний хоёр чухал номыг зохиосон даруй монгол хэлээр Чойжи-Одсэр бандида нар орчуулмагц зургаан ямх буюу төө шахам өндөртэй, тохой орчим өргөнтэй барын хайрцаг, хүрээ бүхий бараг нэгдмэл цуврал мэт хэмжээний судрыг их Юан улсын үед дөрвөлжин үсгээр монгол хэлээр сударчлан хэвлэсэн нь тодорсоор байна ${ }^{7}$.

Учир нь судрын барих залах байрлалаар төө өргөн тохой урт орчим, бүр боломжийн дээд хирээр нарийвчилбал үзүүр сөөмөөс арай өргөн, Үзүүр тохойгоос үл ялиг богино нарийвтар хүрээ хэмжээнээ мөр тэтгэвэл үлэмж зай ашиггүй, тохиромжгүй хоосон болж, үзэж харахад ч ихээхэн эв дүйгүй болох байсан нь тодорхой юм. Иймээс сударчилсан хэвлэлд мөр тэтгээгүй нь зүй ёсны хэрэг бөгөөд зай хэмжээндээ арга эрхгүй тохирч буй хэрэг.

ЭнэХүҮ нэг үгтэй өчүүхэн өөдөс нэгэн хуудсыг төлөөлөх төдийгүй их эртний хэвлэлийн том номыг тодруулан хэлэлцэж тоймлоход чухал үүрэгтэй болох нь илэрхий мэдэгдэж байна. Мөн өмнө хуудсын нэг нүүр буюу 313, 314, 315, 316 дугаар шүлгийн эхээс хагас хугас олдоогүй байснаар төсөөлөхөд ч шинэ өөр хэвлэл гэдэг нь мэдэгдэхүйц болой. Учир нь дээрх уншиж сэргээсэн үгсийн байрлалыг ажиглаваас өрнөдөд буй дэвтэрчилсэн хэвлэлийн монгол Субашидаас илэрхий цөөн үг нэг мөрд байгаа нь хэнд ч тагжгар намхан барын хайрцаг бүхий өөр хэвлэл гэдэг нь тодорхой мэдэгдэх юм. Өөрөөр хэлбэл жинхэнэ эх дурсгалын цөөн үгсийн үсгийн хэсгүүд аяндаа байрлалаараа сударчилсан хэвлэл болохыг илт харуулж байна гэсэн үг. Үүнийг уг тасархайн үсэгтэй төстэй дөрвөлжин үсгийн тусгай шинэ өрмөл үсгээр нөхөн сэргээж сийрүүлсэн зургаас улам ч тод томруун харах бололцоотой / хавсралт зургийг үз/. Галиглан үзүүлбэл:

“ ...ne-

meg-se-ni-yer dü-'ì-rün bui.: no-yan kü-'in 'ir-ge-ni ü-lui qo-ru'u-lan, tö-rö yo-su-'ar al-ba-ni... ". болно 
Дээрх үгсийн утгыг таацаж дүйх монгол орчуулгын хам сэдвээр нь бүрэн үзүүлбэл: (323)

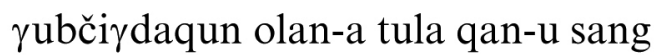

čögöken-iyer dügürmuii uilemji ülii $\gamma$ ubči $\gamma$ daqui: :

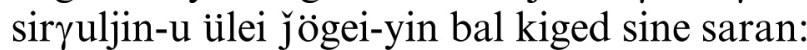

öčỉgüken öčiguiken nemegsen-iyer dügürün bui: :

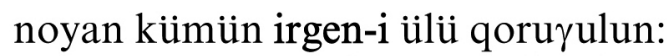

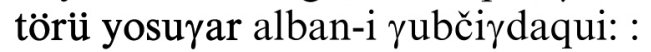

sala modun-ača küji-yin kuičin:

olan čiburibasu modun-i qoqiran bui:: 8

хэмээжээ. Бүр хожуу үед цахар гэвш Лувсанцүлтэмийн орчуулгаар бол

(323) Алимад олноос татах их сан байгуулан өсгөхөд

Асар нэгмөсөн хураалгүй цувуулбал арвин болно.

Адилтгавал шоргоолж нүх малтах, зөгий бал хураах ба

Арвитах шинийн сар өчүүхэн нэмсээр дүүрэх мэт.

(324) Тэргүүлэгч ихэс ноёд олонд хор үл болохыг

Тэгш хэрээр бодож татвар албыг бүтээтүгэй.

Тэр нь сал модны шимийг хүжинд холивол сайн болох боловч

Түүнийг нэн их авбал мод нь хатаж одохтой адил. ${ }^{9}$ гэжээ.

Үүнээ дүгнэн хэлбэл ийнхүү дараалсан хоёр хуудас дарагдсанаас хоёр дахь хуудсаас

ганц бүтэн үгтэй өчүүхэн үлтэрхий үлдэж хоцроод хажуу тойронгийн үгсийн байрлалыг зөв олж шинэ хуудсыг нэмэн тодруулснаар эх бичгийн чухал гэрч баримт болж байна. Дарагдсан хоёр хуудсын дундах нүүр тал цаас хэрэв хамт байсан бол юу ч үлдэлгүй үрэгдэж огт ор үгүй болсон хэрэг. Дээрх байдлаас нягтлан эцэст цохон тэмдэглэхэд нэг үг нь хань хамсаатантайгаа нийлээд нэг хуудас төдийгүй нэгэн номын өөр хэвлэл гэдгийг ч төлөөлж чадах бүрэн үндэс бололцоотой юм гэдэг нь мадаг үгүй магадтай болой.

\section{Ашигласан бүтээлийн жагсаалт}

1. Garudi, On the Fragment Discovered from the Northerm Grottoes Mogaoku of Dunhuang, 2001 (Хятад хэлээр)

2. Mongolian Monuments in 'phags-pa script, Introduction, transliteration, transcription and bibliography, Edited by D.Tumurtogoo, With the collaboration of G.Cecegdari , Language and linguistics Monograph Series 42,Institute of linguistics, Academia Sinica, Taipei, Taiwan 2010

3. B.Otgon, Dunhuang Mogaoku beiqu chutu Mengguwen wenhian yanjiu 2010 (Хятад хэлээр)

4. Dunhuang Academy, Northern Grottoes of Mogaoku, Dunhuang, Vol. III, Beijing, 2004, 417, Table B 163:77

5. В.Otgon, Dunhuang Mogaoku beiqu chutu Mengguwen wenhian yanjiu 2010, 345 дугаар тал.

6. Гунгаажалцан, Сайн үгт эрдэнийн сан нэрт шастир, Монгол тулгар бичгийн цуврал. Бээжин 1989, (Монгол бичгээр) 469 дүгээр тал.

7. Р.Отгонбаатар. Хачин гайхамшигт дурсгал хар хотоос илэрлээ. "Шинжлэх ухаан амьдрал” сэтгүүл. УБ, 2013. №1, 41-44 дүгээр тал.

8. Өөрт байгаа дэлгэр төгсгөл шүлэгтэй эртний бичмэл эхээс буулгав. 36e-37a

9. Эрдэнийн сан Субашид. УБ, 1990 он. 80 дугаар тал. 


\title{
NEW PAGE OF THE SUBHASITARATNANIDHI IN 'PHAGS-PA SCRIPT WHICH PRINTED IN SUTRA STYLE
}

\author{
R.Otgonbaatar \\ Institute of Language and Literature \\ E-mail: onggud@gmail.com
}

In the end of last century and early this century, a library of ancient, rare and precious books and sutras was found, of which some were studied and publicized. Among them, it's to mention the names of researchers of Garid $^{1}$, Tumurtogoo ${ }^{2}$ and Otgon ${ }^{3}$. There were found four pieces of pages of ancient sutra titled 'Treasury of Aphoristic Jewels' printed in 'phags-pa script of Mongolian language in Mongolian sutra format among the books excavated in Muuguu cave /Mogaoku/, Dunhuang. Three of them were arranged and restored a crucial monument with about 30 words in 11 lines written in the middle part of a sutra page. However, one small piece of a sutra page with one 'readable' word was left solely. This article narrates of this piece to become another page to represent. This piece of sutra is registered under the artifact \#B 163:77 and the size is $4,3 \times 6,4 \mathrm{~cm}$ in dimension 4 .

Garid, Inner Mongolian researcher who studied and firstly read the original finding, read and made an suggestion that the word in the front line of the 'readable' word of 'irge-ni' /literally meaning 'the citizen'/ could be read as dïn-gü from its written form or trace. Tumurtogoo, Mongolian researcher transcribed and adopted the reading of the former researcher and read the letter ' 6 ' in the following line after the word 'citizen' properly. Otgon, researcher and teacher at the University of North Western Nationalities in Langjou also studied the piece and left the reading of " $\mathrm{d} 2 \mathrm{ng}$ 2(n)" by Garid ${ }^{5}$ the same as well. Therefore, it was impossible to identify which book this piece was a part of.

The original size of the artifact was $6,4 \times 4,3 \mathrm{~cm}$ in dimension as the researcher documented, where only one word is definite and readable. The certain trait of the last part of written word in the front line and few traits and scratches of the front part of the word in the following line were seen. The only word in these three lines is the word “ ...'ir-ge-ni / the citizen/... ".

From the traits and spot of the front part of the word in the following line, the letter of ' 6 ' makes the word of 'yo-su' (law). It's to note that the word was restored from the visible one third part of the syllable 'ya' and visible one halfth of the syllable 'sa'. If to observe carefully, the front part of the letters of ' $y$ ', (o), 's' and ' $u$ ' are angular, which led directly to propose as 'yosu', 'yo-sun' or 'yo-su-'ar' /according to the law/.

Hence, the word 'ir-ge-ni' /citizen/ in the first line of the 324 stanza , the word ' $d 2 r 2 n$ ' (full) in the last line of the precious $323^{\text {rd }}$ stanza and the word of 'toru yosu-bar' in the second line of the $324^{\text {th }}$ stanza are read.

From these pieces of sutra pages, it becomes evident that the sutra books written by two great wise men Saskya Panditas were translated by Choiji-odser upon their completion of composition and printed in Mongolian language in "phags-pa script in sutra format of series of framed woodcut with six inches in height and a foot in length during the period of Yuan Dynasty ${ }^{6}$.

This one piece of sutra page did represent one whole page and even plays a vital role in restoring and identifying a large book of ancient printing. It's possible to witness it clearly from the restored drawing in special arranged letters of square script /See the attached drawing/. In transcription, it follows as: 
66

...ne-

meg-se-ni-yer dü-'ì-rün bui.:

no-yan kü-'ün 'ir-ge-ni ü-lü qo-ru-

'u-lan, tö-rö yo-su-'ar al-ba-ni... ".

If to show the correlated complete section of Mongolian translation:

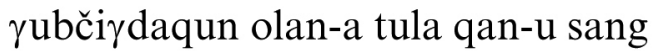

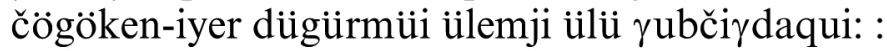

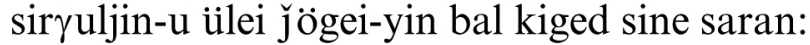

öčiguiken öčỉguiken nemegsen-iyer dügürün bui: :

noyan kümün irgen-i uilii qorurulun:

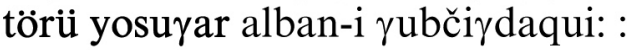

sala modun-ača kiiji-yin kiičiin:

olan čiburibasu modun-i qoqiran bui::

The stanzas are shown as included in the Mongolian' translated into English by James

"A treasury of aphoristic jewels: the Subhasi-

E.Bosson, Indiana University:

taratnanidhi of Sa Skya Pandita in Tibetan and

(323) Because taxes are many, the king's treasury should not be gathered

Together excessively, but should fill up little by little.

The anthill, honey and the new moon

Fill up little by little

(324) Rulers should gather taxes in proper manner

Not harming their subjects

If much essence of incense drips from the Sala tree

It will dry up'

As a conclusion, a small piece of a sutra identification and location of the words written in rows. In this regards, it's possible and fully page with one readable word is left from two following pages and becomes a significant evidence of literary culture by finding the exact potential to represent not only a whole page but an independent print of an entire book.

1. Garudi, On the Fragment Discovered from the Northerm Grottoes Mogaoku of Dunhuang, 2001 (in Chinese)

2. Mongolian Monuments in 'phags-pa script, Introduction, transliteration, transcription and bibliography, Edited by D.Tumurtogoo, With the collaboration of G.Cecegdari, Language and linguistics Monograph Series 42,Institute of linguistics, Academia Sinica, Taipei, Taiwan 2010

3. B.Otgon, Dunhuang Mogaoku beiqu chutu Mengguwen wenhian yanjiu 2010 (in Chinese)

4. Dunhuang Academy, Northern Grottoes of Mogaoku, Dunhuang, Vol. Ill, Beijing, 2004, 417, Table B 163:77

5. B.Otgon, Dunhuang Mogaoku beiqu chutu Mengguwen wenhian yanjiu 2010, p345.

6. Р.Отгонбаатар. Хачин гайхамшигт дурсгал хар хотоос илэрлээ. "Шинжлэх ухаан амьдрал” сэтгүҮл. УБ, 2013. №1, 41-44 дүгээр тал. 


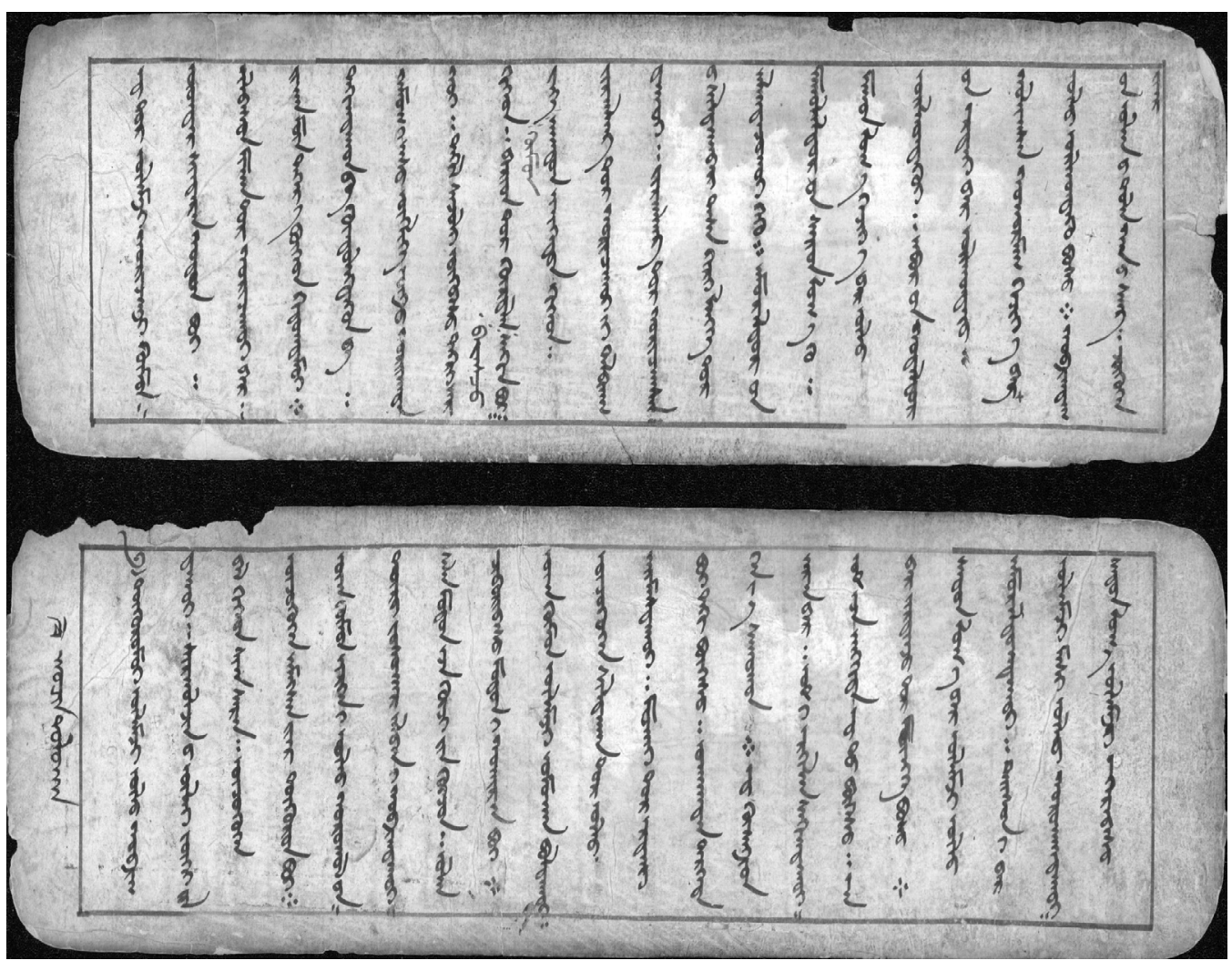

Тэнхруүлсэн иүлгийн тохирох эх 


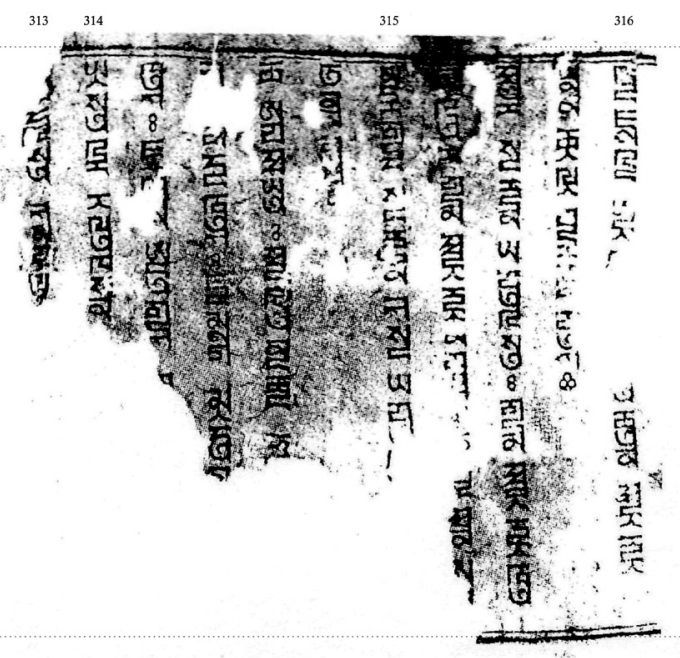

Өмнөх хуудсын нэгэн нүҮр
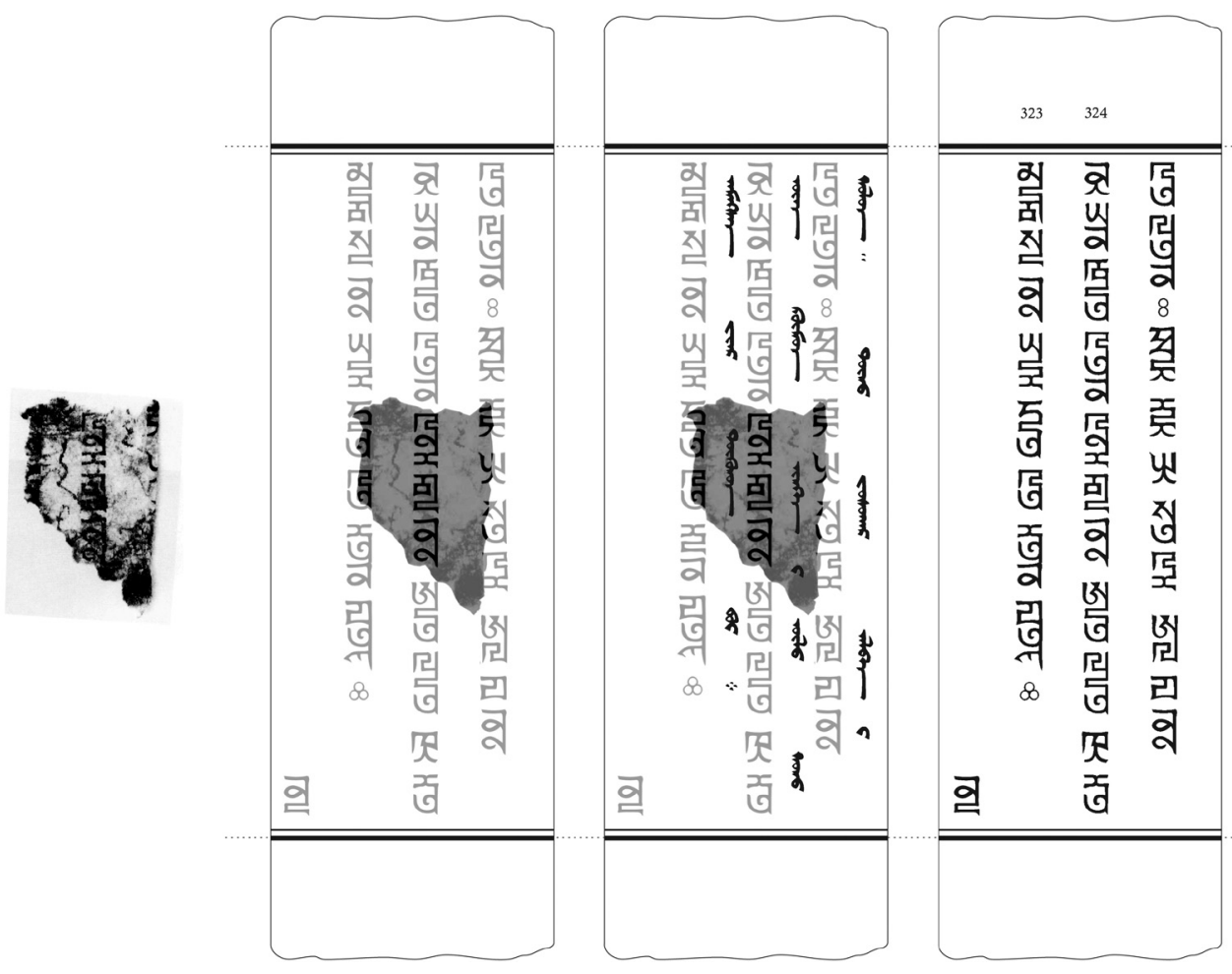

Тамтархайг тэнхрүүлэн сэргээсэн нь 